\title{
JNPH
}

Volume 7 No. 2 (Oktober 2019)

(C) The Author(s) 2019

\section{RESIKO PENYALAHGUNAAN NARKOBA PADA SISWA SMP DI KOTA BENGKULU}

\section{RISK OF DRUG ABUSE AMONG JUNIOR HIGH SCHOOL STUDENT IN BENGKULU}

\author{
MARIZA ARFIANTI ${ }^{1}$, DILFERA HERMIATI ${ }^{2}$ \\ PROGRAM STUDI PROFESI NERS, FAKULTAS ILMU KESEHATAN \\ PROGRAM STUDI KEPERAWATAN (DIII), FAKULTAS ILMU KESEHATAN, \\ UNIVERSITAS DEHASEN BENGKULU \\ Email: mariza@unived.ac.id
}

\begin{abstract}
ABSTRAK
Korban penyalahgunaan narkoba bukan hanya pada orang dewasa, mahasiswa, tetapin juga pelajar SMU sampai pelajar setingkat SD. Berdasarkan hasil survei tahun 2017, proporsi pelajar penyalahguna narkoba sebesar 24\%, kedua terbesar setelah kelompok pekerja (59\%), sedangkan penyalahguna narkoba pada populasi umum adalah sebesar 17\%. Penelitian ini bertujuan untuk menentukan tingkat resiko penyalahgunaan narkoba pada siswa SMP di Kota Bengkulu. Penelitian ini merupakan penelitian deskriptif kualitatif menggunakan desain cross sectional yang dilaksanakan di SMP 4, SMP 6, SMP 7, dan SMP 10 Kota Bengkulu. Populasi penelitian ini adalah semua siswa kelas IX di Kota Bengkulu. Tenik pengambilan sampel yang digunakan adalah stratified random sampling sehingga didapatkan jumlah sampel sebanyak 200 orang. Analisa data dilakukan secara univariat dan bivariat. Hasil penelitian menunjukkan bahwa lebih dari sebagian responden (57\%) beresiko tinggi melakukan penyalahgunaan narkoba. Terdapat empat variabel yang berhubungan dengan resiko penyalahgunaan narkoba pada siswa SMP di Kota Bengkulu yaitu jenis kelamin $(\rho=0,027, \mathrm{OR}=1.903, \mathrm{CI}$ : 1.073-3.377), keluarga $(\rho=0,020, \mathrm{OR}=2,005, \mathrm{CI}: 1.112-3.614)$, sekolah $(\rho=0,02, \mathrm{OR}=2.433, \mathrm{CI}: 1.371$ 4.318), dan masyarakat ( $\rho=0,003 \mathrm{OR}=2.406, \mathrm{CI}: 1.354-4.274)$. disarankan pada perawat dan tenaga kesehatan agar dapat meningkatkan promosi pencegahan penyalahgunaan narkoba pada siswa SMP. Bagi orangtua dan masyarakat agar dapat meningkatkan kedisiplinan dan pengawasan pada anak remaja.
\end{abstract}

Kata Kunci: penyalahgunaan, narkoba, remaja

\begin{abstract}
Victims of drug abuse not only in adults and college students but also high school and elementary level students. Based on the results of the 2017 survey, the proportion of student drug abusers is $24 \%$, the second largest after the group of workers (59\%), while the drug user in the general population is $17 \%$. This study aims to determine the level of risk of drug abuse among junior high school students in Bengkulu City. This research is a qualitative descriptive study using cross sectional design which was carried out in SMP 4, SMP 6, SMP 7, and SMP 10 Bengkulu City. The population of this study were all grade IX students in Bengkulu City. The
\end{abstract}


sampling technique used was stratified random sampling to obtain a total sample of 200 people. Data analysis was carried out univariately and bivariately. The results showed that more than half of the respondents (57\%) were at high risk of drug abuse. There are four variables related to the risk of drug abuse in junior high school students in the city of Bengkulu, namely gender $(\rho=0.027, \mathrm{OR}=1.903, \mathrm{CI}: 1.073-3.377)$, family $(\rho=0.020, \mathrm{OR}=2.005, \mathrm{CI}: 1.112-3.614)$, school $(\rho=0.02, \mathrm{OR}=2,433, \mathrm{CI}: 1,371-4,318)$, and community $(\rho=0.003$ OR $=2,406$, CI: $1,354-4,274)$. It is recommended for nurses and health workers to be able to increase the promotion of prevention of drug abuse in junior high school students. For parents and the community to be able to improve discipline and supervision of adolescents.

Keywords: abuse, drugs, adolescents

\section{PENDAHULUAN}

Narkoba (narkoba dan Obat/Bahan Berbahaya), disebut juga NAPZA (Narkotika, Psikotropika dan Zat Adiktif lain) adalah obat bahan atau zat bukan makanan yang jika diminum, diisap, dihirup, ditelan, atau disuntikan, berpengaruh pada kerja otak yang bila masuk kedalam tubuh manusia akan mempengaruhi tubuh terutama otak (susunan saraf pusat), sehingga menyebabkan gangguan kesehatan fisik, psikis, dan fungsi sosialnya karena terjadi kebiasaan, ketagihan (adiksi) serta ketergantungan (dependensi) terhadap NAPZA tersebut. Berdasarkan jenisnya narkoba dapat menyebabkan perubahan pada suasana hati, perubahan pada pikiran dan perubahan perilaku

Penyalahgunaan narkoba masih merupakan masalah yang serius di Indonesia. Jumlah penyalahguna narkoba di Indonesia diperkirakan telah mencapai sekitar 3,5 juta pada tahun 2017, dimana 1,4 juta adalah pengguna biasa dan hampir satu juta telah menjadi pecandu narkoba (Priyasmoro, 2018).

Korban penyalahgunaan narkoba bukan hanya pada orang dewasa, mahasiswa, tetapin juga pelajar SMU sampai pelajar setingkat SD (Infodatin Anti Narkoba Sedunia, 2017). Berdasarkan hasil survei tahun 2017, proporsi pelajar penyalahguna narkoba sebesar $24 \%$, kedua terbesar setelah kelompok pekerja (59\%), sedangkan penyalahguna narkoba pada populasi umum adalah sebesar $17 \%$ (Survei Nasional Penyalahguna Narkoba di 34 Provinsi Tahun 2017). Remaja pada usianya yang beranjak dari kanak-kanak menuju kepada dewasa mengalami perubahan secara psikologis dan emosional (Hurlock, 2003 dalam Setiawan, 2017). Secara emosional terkadang remaja sulit mengendalikan dirinya dalam beberapa situasi seperti keinginan yang harus dipenuhi, dan apabila tidah terpenuhi maka remaja akan muncul rasa kecewa, sedih atau bahkan frustasi. Apabila tidak mendapatkan arahan atau bimbingan maka remaja akan berpotensi melakukan apapun untuk menenagkan dirinya. Hal ini yang membuat remaja berpotensi melakukan penyalahgunaan narkoba (Yusuf, 2016).

Dikhawatirkan bahwa dampak dari makin maraknya kasus-kasus penyalahgunaan narkoba ialah pada akhirnya terjadi lost generation (hilangnya satu generasi). Hal ini berdasarkan asumsi bahwa sebagian besar penyalahguna narkoba adalah kelompok usia muda (Purwatiningsih, 2001). Penyalahgunaan narkoba secara fisik dapat menimbulkan gangguan pada system saraf seperti kejang-kejang, halusinasi, gangguan kesadaran, dan kerusakan saraf tepi. Dampak secara psikis yaitu timbulnya gangguan persepsi, daya pikir, kreasi, dan emosi. Dampak secara sosial yaitu timbulnya sikap anti sosial dan asusila, dikucilkan oleh lingkungan, pendidikan menjadi terganggu, dan masa depan suram.

Pada tahun 2014, angka prevalensi penyalahgunaan narkoba Provinsi Bengkulu yaitu $1,88 \%$ atau setara dengan 25.784 orang dari 1.370.000 orang pada usia 10-59 tahun. Pada tahun 2015, angka prevalensi 
penyalahgunaan narkoba Provinsi Bengkulu turun menjadi sebesar $1,62 \%$ atau setara dengan 22.602 orang dari 1.392 .800 orang pada usia 10-59 tahun (BNN Kota Bengkulu, 2016). Pada tahun 2017, prevalensi jumlah penyalahgunaa narkoba Provinsi Bengkulu naik kembali menjadi $1,68 \%$ dengan jumlah penyalahguna sebesar 24.118 orang dari 1.436.700 orang dengan usia 10-59 tahun (Puslitdatin BNN, 2017). Penyalahgunaan itu dapat dicegah upaya deteksi dini terhadap kecenderungan penyalahgunaan narkoba

\section{METODE}

Penelitian ini adalah penelitian analitik kuantitatif, dengan desain penelitian cross sectional. Lokasi penelitian ini adalah di SMPN 4, SMPN 7, SMPN 10, dan SMPN 16 Kota Bengkulu. Penelitian ini dilaksanakan pada bulan Maret-September 2019.

Variabel independen penelitian ini adalah usia, jenis kelamin, keluarga, sekolah, dan masyarakat. Variabel dependen penelitian ini adalah resiko penyalahgunaan narkoba. Populasi penelitian ini adalah seluruh siswa siswi kelas IX di Kota Bengkulu. Pengambilan sampel dilakukan dengan teknik stratified random sampling sehingga didapatkan total sampel berjumlah 200 responden. Pada penelitian ini data dikumpulkan dengan mengunakan kuisioner. Analisis yang digunakan adalah analisis univariat dan bivariat.

\section{HASIL}

\section{Analisis Univariat}

\section{a. Usia}

Tabel 1. Distribusi frekuensi responden berdasarkan usia

\begin{tabular}{ccc}
\hline Usia & Frekuensi & Persentase \\
\hline $\begin{array}{l}\text { Remaja Awal (10- } \\
14 \text { tahun) }\end{array}$ & 143 & 71,5 \\
\hline $\begin{array}{c}\text { Remaja Akhir (15- } \\
19 \text { tahun) }\end{array}$ & 57 & 28,5 \\
\hline
\end{tabular}

Tabel 1 menunjukkan bahwa hampir seluruh responden $(71,5 \%)$ merupakan remaja awal.

\section{b. Jenis Kelamin}

Tabel 2. Distribusi frekuensi responden berdasarkan jenis kelamin

\begin{tabular}{ccc}
\hline Jenis Kelamin & Frekuensi & Persentase \\
\hline Perempuan & 110 & 55 \\
\hline Laki-laki & 90 & 45 \\
\hline
\end{tabular}

Tabel 2 menunjukkan bahwa lebih sebagian responden $(55 \%)$ berjenis kelamin perempuan.

\section{c. Keluarga}

Tabel 3. Distribusi frekuensi responden berdasarkan faktor keluarga

\begin{tabular}{ccc}
\hline Keluarga & Frekuensi & Persentase \\
\hline Tidak mendukung & 121 & 60,5 \\
\hline Mendukung & 79 & 39,5 \\
\hline
\end{tabular}

Tabel 3 menunjukkan bahwa sebagian besar responden $(60,5 \%)$ memiliki keluarga yang tidak mendukung terjadinya resiko penyalahgunaan narkoba.

\section{d. Sekolah}

Tabel 4. Distribusi frekuensi responden berdasarkan faktor sekolah

\begin{tabular}{ccc}
\hline Sekolah & Frekuensi & Persentase \\
\hline Tidak mendukung & 96 & 48 \\
\hline Mendukung & 104 & 52 \\
\hline
\end{tabular}

Tabel 4 menunjukkan bahwa lebih dari sebagian responden $(52 \%)$ berada di lingkungan sekolah yang mendukung terjadinya resiko penyalahgunaan narkoba.

e. Masyarakat

Tabel 5. Distribusi frekuensi responden berdasarkan faktor masyarakat 


\begin{tabular}{ccc}
\hline Masyarakat & Frekuensi & Persentase \\
\hline Tidak mendukung & 101 & 50,5 \\
\hline Mendukung & 99 & 49,5 \\
\hline
\end{tabular}

Tabel 5 menunjukkan bahwa hampir sebagian responden $(49,5 \%)$ tinggal di dalam kondisi masyarakat yang mendukung terjadinya resiko penyalahgunaan narkoba.

\section{f. Resiko Penyalahgunaan Narkoba}

Tabel 6. Distribusi frekuensi responden berdasarkan resiko penyalahgunaan narkoba

\begin{tabular}{|c|c|c|c|c|c|c|c|}
\hline \multirow{3}{*}{ Usia } & \multicolumn{4}{|c|}{$\begin{array}{c}\text { Resiko } \\
\text { Penyalahgunaan } \\
\text { Narkoba }\end{array}$} & \multirow{2}{*}{\multicolumn{2}{|c|}{ Total }} & \multirow[t]{3}{*}{$\begin{array}{c}\rho \\
\text { value }\end{array}$} \\
\hline & \multicolumn{2}{|c|}{$\begin{array}{r}\text { Resiko } \\
\text { Rendah }\end{array}$} & \multicolumn{2}{|c|}{$\begin{array}{l}\text { Resiko } \\
\text { Tinggi }\end{array}$} & & & \\
\hline & $\mathbf{F}$ & $\%$ & F & $\%$ & $\mathbf{F}$ & $\%$ & \\
\hline $\begin{array}{c}\text { Remaja } \\
\text { Awal }\end{array}$ & 69 & 48,3 & 74 & 51,7 & 143 & 100 & 017 \\
\hline $\begin{array}{l}\text { Remaja } \\
\text { Akhir }\end{array}$ & 17 & 29,8 & 40 & 70,2 & 57 & 100 & \\
\hline
\end{tabular}

Tabel 6 menunjukkan bahwa lebih dari sebagian responden (57\%) beresiko tinggi terhadap penyalahgunaan narkoba.

\section{Analisis Bivariat}

Analisis ini digunakan untuk mengetahui hubungan antara faktor usia, jenis kelamin, keluarga, sekolah, dan masyarakat terhadap resiko penyalahgunaan narkoba pada Siswa SMP di Kota Bengkulu.

\section{a. Hubungan usia dan resiko penyalahgunaan narkoba}

Tabel 7 Hubungan usia dengan resiko penyalahgunaan narkoba pada siswa SMP di Kota Bengkulu

\begin{tabular}{|c|c|c|c|c|c|c|c|}
\hline \multirow{3}{*}{ Usia } & \multicolumn{4}{|c|}{$\begin{array}{c}\text { Resiko } \\
\text { Penyalahgunaan } \\
\text { Narkoba } \\
\end{array}$} & \multirow{2}{*}{\multicolumn{2}{|c|}{ Total }} & \multirow[t]{3}{*}{$\begin{array}{c}\rho \\
\text { value }\end{array}$} \\
\hline & \multicolumn{2}{|c|}{$\begin{array}{r}\text { Resiko } \\
\text { Rendah } \\
\end{array}$} & \multicolumn{2}{|c|}{$\begin{array}{r}\text { Resiko } \\
\text { Tinggi } \\
\end{array}$} & & & \\
\hline & $\mathbf{F}$ & $\%$ & $\mathbf{F}$ & $\%$ & $\mathbf{F}$ & $\%$ & \\
\hline $\begin{array}{c}\text { Remaja } \\
\text { Awal }\end{array}$ & 69 & 48,3 & 74 & 51,7 & 143 & 100 & \\
\hline $\begin{array}{c}\text { Remaja } \\
\text { Akhir }\end{array}$ & 17 & 29,8 & 40 & 70,2 & 57 & 100 & 0,17 \\
\hline
\end{tabular}

Tabel 7 menunjukkan bahwa lebih sebagian responden remaja awal $(51,7 \%)$ beresiko tinggi melakukan penyalahgunaan narkoba dan sebagian besar responden remaja akhir $(70,2 \%)$ beresiko tinggi melakukan penyalahgunaan narkoba.

Hasil uji statistik chi-square (pearson chi square) didapatkan nilai $\rho$ value $=0,17>$ 0,05 maka dapat disimpulkan bahwa tidak ada hubungan signifikan antara usia dengan resiko penyalahgunaan narkoba pada siswa SMP di Kota Bengkulu.

b. Hubungan jenis kelamin dan resiko penyalahgunaan narkoba

Tabel 8. Hubungan jenis kelamin dengan resiko penyalahgunaan narkoba pada siswa SMP di Kota Bengkulu

\begin{tabular}{|c|c|c|c|c|c|c|c|}
\hline \multirow{3}{*}{$\begin{array}{c}\text { Jenis } \\
\text { Kelamin }\end{array}$} & \multicolumn{4}{|c|}{$\begin{array}{c}\text { Resiko } \\
\text { Penyalahgunaan } \\
\text { Narkoba } \\
\end{array}$} & \multirow{2}{*}{\multicolumn{2}{|c|}{ Total }} & \multirow[t]{3}{*}{$\begin{array}{c}\rho \\
\text { value }\end{array}$} \\
\hline & \multicolumn{2}{|c|}{$\begin{array}{r}\text { Resiko } \\
\text { Rendah }\end{array}$} & \multicolumn{2}{|c|}{$\begin{array}{c}\text { Resiko } \\
\text { Tinggi }\end{array}$} & & & \\
\hline & $\mathbf{F}$ & $\%$ & $\mathbf{F}$ & $\%$ & $\mathbf{F}$ & $\%$ & \\
\hline Perempuan & 55 & 50 & 55 & 50 & 110 & 100 & $0 \Omega$ \\
\hline Laki-laki & 31 & 34,4 & 59 & 65,6 & 90 & 100 & $0,0<1$ \\
\hline
\end{tabular}

Tabel 8 menunjukkan bahwa sebagian responden berjenis kelamin perempuan $(50 \%)$ beresiko tinggi melakukan penyalahgunaan narkoba dan lebih dari sebagian responden berjenis kelamin laki-laki $(65,6 \%)$ beresiko tinggi melakukan penyalahgunaan narkoba.

Hasil uji statistik chi-square (pearson chi square) didapatkan nilai $\rho$ value $=0,027<$ 0,05 maka dapat disimpulkan bahwa ada hubungan signifikan antara jenis kelamin dengan resiko penyalahgunaan narkoba pada 
siswa SMP di Kota Bengkulu. Dari analisis keeratan hubungan antara dua variabel didapatkan $\mathrm{OR}=1.903$ (95\% CI: 1.073-3.377), artinya remaja laki-laki beresiko tinggi 1.903 kali menyalahgunakan narkoba dibandingkan dengan remaja perempuan.

c. Hubungan keluarga dan resiko penyalahgunaan narkoba

Tabel 9. Hubungan keluarga dengan resiko penyalahgunaan narkoba pada siswa SMP di Kota Bengkulu

\begin{tabular}{|c|c|c|c|c|c|c|c|}
\hline \multirow{3}{*}{ Keluarga } & \multicolumn{4}{|c|}{$\begin{array}{c}\text { Resiko } \\
\text { Penyalahgunaan } \\
\text { Narkoba } \\
\end{array}$} & \multirow{2}{*}{\multicolumn{2}{|c|}{ Total }} & \multirow[t]{3}{*}{$\begin{array}{c}\rho \\
\text { value }\end{array}$} \\
\hline & \multicolumn{2}{|c|}{$\begin{array}{r}\text { Resiko } \\
\text { Rendah } \\
\end{array}$} & \multicolumn{2}{|c|}{$\begin{array}{l}\text { Resiko } \\
\text { Tinggi } \\
\end{array}$} & & & \\
\hline & $\mathbf{F}$ & $\%$ & $\mathbf{F}$ & $\%$ & $\mathbf{F}$ & $\%$ & \\
\hline Tidak & 60 & 49,6 & 61 & 50,4 & 121 & 100 & \\
\hline $\begin{array}{l}\text { mendukung } \\
\text { Mendukung }\end{array}$ & 26 & 32,9 & 53 & 67,1 & 79 & 100 & 0,020 \\
\hline
\end{tabular}

Tabel 9 menunjukkan bahwa lebih dari sebagian responden yang memiliki keluarga yang tidak mendukung terjadinya resiko penyalahgunaan narkoba $(50,4 \%)$ beresiko tinggi melakukan penyalahgunaan narkoba, dan lebih dari sebagian responden yang memiliki keluarga yang mendukung terjadinya resiko penyalahgunaan narkoba $(67,1 \%)$ beresiko tinggi melakukan penyalahgunaan narkoba.

Hasil uji statistik chi-square (pearson chi square) didapatkan nilai $\rho$ value $=0,020<$ 0,05 maka dapat disimpulkan bahwa ada hubungan signifikan antara keluarga dengan resiko penyalahgunaan narkoba pada siswa SMP di Kota Bengkulu. Dari analisis keeratan hubungan antara dua variabel didapatkan $\mathrm{OR}=2,005 \quad(95 \% \mathrm{CI}: 1.112-3.614)$, artinya remaja dari keluarga yang mendukung terjadinya resiko penyalahgunaan 2,005 kali lebih beresiko melakukan penyalahgunaan narkoba dibandingkan dengan remaja dari keluarga yang tidak mendukung terjadinya resiko penyalahgunaan narkoba.
d. Hubungan sekolah dan resiko penyalahgunaan narkoba

Tabel 10. Hubungan sekolah dengan resiko penyalahgunaan narkoba pada siswa SMP di Kota Bengkulu

\begin{tabular}{|c|c|c|c|c|c|c|c|}
\hline \multirow{3}{*}{ Sekolah } & \multicolumn{4}{|c|}{$\begin{array}{c}\text { Resiko } \\
\text { Penyalahgunaan } \\
\text { Narkoba } \\
\end{array}$} & \multirow{2}{*}{\multicolumn{2}{|c|}{ Total }} & \multirow{3}{*}{$\begin{array}{c}\rho \\
\text { value }\end{array}$} \\
\hline & \multicolumn{2}{|c|}{$\begin{array}{r}\text { Resiko } \\
\text { Rendah } \\
\end{array}$} & \multicolumn{2}{|c|}{$\begin{array}{l}\text { Resiko } \\
\text { Tinggi } \\
\end{array}$} & & & \\
\hline & $\mathbf{F}$ & $\%$ & $\mathbf{F}$ & $\%$ & $\mathbf{F}$ & $\%$ & \\
\hline Tidak & 52 & 54,2 & 44 & 45,8 & 96 & 100 & \\
\hline $\begin{array}{l}\text { mendukung } \\
\text { Mendukung }\end{array}$ & 34 & 32,7 & 70 & 67,3 & 104 & 100 & 0,002 \\
\hline
\end{tabular}

Tabel 10 menunjukkan bahwa hampir sebagian responden yang memiliki sekolah yang tidak mendukung terjadinya resiko penyalahgunaan narkoba $(45,8 \%)$ beresiko tinggi melakukan penyalahgunaan narkoba, dan lebih dari sebagian responden yang memiliki sekolah yang mendukung terjadinya resiko penyalahgunaan narkoba $(67,3 \%)$ beresiko tinggi melakukan penyalahgunaan narkoba.

Hasil uji statistik chi-square (pearson chi square) didapatkan nilai $\rho$ value $=0,02<$ 0,05 maka dapat disimpulkan bahwa ada hubungan signifikan antara sekolah dengan resiko penyalahgunaan narkoba pada siswa SMP di Kota Bengkulu. Dari analisis keeratan hubungan antara dua variabel didapatkan $\mathrm{OR}=2.433 \quad(95 \%$ CI: 1.371-4.318), artinya remaja dari sekolah yang mendukung terjadinya resiko penyalahgunaan 2,433 kali lebih beresiko melakukan penyalahgunaan narkoba dibandingkan dengan remaja dari sekolah yang tidak mendukung terjadinya resiko penyalahgunaan narkoba.

e. Hubungan masyarakat dan resiko
penyalahgunaan narkoba

Tabel 11 Hubungan masyarakat dengan resiko penyalahgunaan narkoba pada siswa SMP di Kota Bengkulu 


\begin{tabular}{|c|c|c|c|c|c|c|c|}
\hline \multirow{3}{*}{ Masyarakat } & \multicolumn{4}{|c|}{$\begin{array}{c}\text { Resiko } \\
\text { Penyalahgunaan } \\
\text { Narkoba }\end{array}$} & \multirow{2}{*}{\multicolumn{2}{|c|}{ Total }} & \multirow{3}{*}{$\begin{array}{c}\rho \\
\text { valu } \\
\mathbf{e}\end{array}$} \\
\hline & \multicolumn{2}{|c|}{$\begin{array}{r}\text { Resiko } \\
\text { Rendah }\end{array}$} & \multicolumn{2}{|c|}{$\begin{array}{l}\text { Resiko } \\
\text { Tinggi }\end{array}$} & & & \\
\hline & $\mathbf{F}$ & $\%$ & $\mathbf{F}$ & $\%$ & $\mathbf{F}$ & $\%$ & \\
\hline $\begin{array}{c}\text { Tidak } \\
\text { mendukung } \\
\text { Mendukung }\end{array}$ & $\begin{array}{l}54 \\
32\end{array}$ & $\begin{array}{l}53,5 \\
32,3\end{array}$ & $\begin{array}{l}47 \\
67\end{array}$ & $\begin{array}{l}46,5 \\
67,7\end{array}$ & $\begin{array}{c}101 \\
99\end{array}$ & $\begin{array}{l}100 \\
100\end{array}$ & $\begin{array}{c}0,00 \\
3\end{array}$ \\
\hline
\end{tabular}

Tabel 11 menunjukkan bahwa hampir sebagian responden yang tinggal di lingkungan masyarakat yang tidak mendukung terjadinya resiko penyalahgunaan narkoba $(46,5 \%)$ beresiko tinggi melakukan penyalahgunaan narkoba, dan lebih dari sebagian responden yang tinggal di lingkungan masyarakat yang mendukung terjadinya resiko penyalahgunaan narkoba $(67,7 \%)$ beresiko tinggi melakukan penyalahgunaan narkoba.

Hasil uji statistik chi-square (pearson chi square) didapatkan nilai $\rho$ value $=0,003<$ 0,05 maka dapat disimpulkan bahwa ada hubungan signifikan antara masyarakat dengan resiko penyalahgunaan narkoba pada siswa SMP di Kota Bengkulu. Dari analisis keeratan hubungan antara dua variabel didapatkan $\mathrm{OR}=2.406$ (95\% CI: 1.354-4.274), artinya remaja dari masyarakat yang mendukung terjadinya resiko penyalahgunaan 2.406 kali lebih beresiko melakukan penyalahgunaan narkoba dibandingkan dengan remaja dari masyarakat yang tidak mendukung terjadinya resiko penyalahgunaan narkoba.

\section{PEMBAHASAN}

\section{a. Hubungan usia dengan resiko penyalahgunaan narkoba}

Dari hasil penelitian ini didapatkan bahwa lebih dari sebagian responden remaja awal $(51,7 \%)$ beresiko tinggi melakukan penyalahgunaan narkoba, dan hampir seluruh responden remaja akhir $(70,2 \%)$ beresiko tinggi melakukan penyalahgunaan narkoba. Remaja merupakan suatu periode pada tahap transisi yang penuh dengan storm dan stress.
Masa pubertas merupakan periode penuh masalah, benturan-benturan dalam penyesuaian diri yang emosional, suatu masa dimana mood remaja berubah secara ekstrim antara suka dan tidak suka, ceria-depresi, berani-malu (Hall 1996 dalam Hurriyati, 2010).

Survey penggunaan obat-obatan pada kondisi umum menunjukkan bahwa penggunaan obat-obatan pada orang yang lebih tua lebih rendah daripada penggunaan obat-obatan pada orang yang berusia muda. Data menunjukkan bahwa level puncak penggunaan obat-obatan adalah pada usia 1825 tahun. Banyak penelitian menyatakan bahwa usia remaja mulai dari remaja awal sampai remaja akhir merupakan masa kritis dimana dimulainya penggunaan obat-obatan. Beberapa anak muda menggunakan obatobatan sebagai bentuk koping terhadap masalah sosial dan psikologis yang dialaminya selama fase remaja sampai dewasa muda (World Drug Report, 2018).

Ciri remaja yaitu ingin tahu, ingin mencoba, dan cenderung melawan otoritas dalam rangka mencari identitas diri merupakan hal-hal yang menyebabkan remaja menggunakan NAPZA (Martono \& Joewana, 2006 dalam Tambunan, Sahar, dan Hastono, 2008). Hurlock (2000) mengatakan masa ini adalah masa remaja memusatkan dirinya pada perilaku yang dihubungkan dengan status dewasa, yaitu merokok, menggunakan minuman kers, obat-obatan, dan terlibat dalam perbuatan seks. Remaja menganggap hal ini memberikan citra hebat dan bisa seperti yang lain.

Pada penelitian ini didapatkan nilai $\rho$ value $=0,17$ yang berarti tidak ada hubungan yang signifikan antara usia dengan resiko penyalahgunaan narkoba pada siswa SMP di Kota Bengkulu. Hal ini sejalan dengan penelitian Jaji, 2009 yang menyatakan bahwa tidak terdapat hubungan yang bermakna antara usia dan resiko penyalahgunaan narkoba pada remaja SMP dan SMA. Ketidakbermaknaan ini dimungkinkan dikarenakan menurut Efendi dilihat dari tahap keterlibatan secara umum remaja 
menyalahgunakan NAPZA yaitu kontak pertama bisa terjadi pada usia remaja, ketika berkumpul dengan teman-teman, dan biasanya tidak akan melanjutkan pengalaman pertama ini. Sedangkan pada tahap eksperimental setelah kontak pertama, beberapa mungkin melanjutkan proses eksperimental sengan zat-zat lain dan sebagian besar setelah tahu akan berhenti pada tahap ini.

\section{b. Hubungan jenis kelamin dengan resiko penyalahgunaan narkoba}

Dari hasil penelitian ini didapatkan bahwa lebih dari sebagian responden yang berjenis kelamin laki-laki $(65,6 \%)$ beresiko tinggi melakukan penyalahgunaan narkoba. Hal ini serupa dengan hasil survey kesehatan reproduksi remaja Indonesia bahwa laki-laki berpeluang 20 kali dalam menggunakan narkoba.

Remaja laki-laki lebih ambisius dan memiliki tingkat agresi yang lebih tinggi dibandingkan dengan remaja perempuan. Tingginya kasus penyalahgunaan NAPZA pada laki-laki disebabkan oleh beberapa hal antara lain kepribadian laki-laki yang cenderung ingin terlihat berani dan jantan, cenderung lebih senang bergaul secara berkelompok sehingga mereka akan melakukan berbagai hal agar dapat diterima dalam kelompok tersebut sehingga jika terdapat salah satu anggota kelompok yang menggunakan narkoba maka anggota kelompok yang lain cenderung mengikuti perilaku menyimpang tersebut (Afandi dkk, 2009; Kartono, 2010; dan Shekarchizadeh dkk, 2012 dalam Nur'artavia, 2017).

Pada penelitian ini didapatkan nilai $\rho$ value $=0,027$ yang artinya ada hubungan yang signifikan antara jenis kelamin dengan resiko penyalahgunaan narkoba pada siswa SMP di Kota Bengkulu. Penelitian ini juga sejalan dengan penelitian Rahanie, Nuning, dan Evie, 2002 yang menyatakan bahwa jenis kelamin berhubungan dengan penyalahgunaan NAPZA pada siswa SMU.

Pada penelitian ini didapatkan
$\mathrm{OR}=1.903$ yang artinya remaja laki-laki beresiko tinggi 1.903 kali melakukan penyalahgunaan narkoba dibandingkan dengan remaja perempuan. Terdapat bukti perbedaan jenis kelamin dengan perilaku kenakalan remaja dimana remaja pria cenderung lebih nakal dibandingkan remaja wanita (Simon, 1996 dalam Rahanie, Nuning, dan Evie, 2002).

\section{c. Hubungan keluarga dengan resiko penyalahgunaan narkoba}

Pada penelitian ini didapatkan bahwa sebagian besar responden yang memiliki keluarga yang mendukung terjadinya resiko penyalahgunaan narkoba $(67,1 \%)$ beresiko tinggi melakukan penyalahgunaan narkoba.

Lingkungan keluarga yang tidak harmonis dapat berpengaruh pada remaja karena menyebabkan remaja kehilangan role model. Ketidakharmonisan dalam keluarga menjadi pendorong remaja menggunakan NAPZA (Mc. Murray 1994, Sindelar \& Fielin, 2001 dalam Tambunan, Sahar, dan Hastono, 2008). Keutuhan dalam keluarga juga dapat berpengaruh terhadap psikologis seorang anak, sehingga apabila psikologis anak terganggu maka anak akan lebih mudah lari dalam pergaulan negatif di luar rumah dan anak juga akan mudah terjerumus dalam penyalahgunaan NAPZA (Hawari, 2009 dalam Asmoro dan Melaniani, 2015).

Pada penelitian ini didapatkan nilai $\rho$ value $=0,020$ yang artinya ada hubungan yang signifikan antara keluarga dengan resiko penyalahgunaan narkoba pada siswa SMP di Kota Bengkulu. Penelitian Asni, Rahma, dan Sarake, 2013 menyatakan bahwa siswa yang pernah menyalahgunakan narkoba lebih banyak yang memiliki keluarga tidak harmonis dibandingkan dengan siswa yang menganggap keluarganya harmonis.

Pada penelitian ini didapatkan nilai $\mathrm{OR}=2.005$ artinya remaja dari keluarga yang mendukung terjadinya resiko penyalahgunaan narkoba 2,005 kali beresiko tinggi melakukan penyalahgunaan narkoba dibandingkan remaja dari keluarga yang tidak mendukung 
terjadinya penyalahgunaan narkoba. Penelitian ini sejalan dengan penelitian Hawari yang menjelaskan bahwa remaja dengan kondisi keluarga yang tidak harmonis mempunyai resiko relative 7,9 kali menyalahgunakan narkoba. selain itu, penelitian menunjukkan bahwa hubungan kedua orang tua yang tidak harmonis, hubungan orang tua dan anak yang tidak sehat, suasana rumah tangga yang tegang dan tanpa kehangatan, orangtua sibuk dan jarang di rumah, atau orang tua mempunyai kelainan kepribadian turut mendorong anak terjerumus dalam penyalahgunaan narkoba (Asni, Rahma, dan Sarake, 2013).

\section{d. Hubungan sekolah dengan resiko penyalahgunaan narkoba}

Pada penelitian ini didapatkan lebih dari sebagian responden yang memiliki sekolah yang mendukung terjadinya resiko penyalahgunaan narkoba $(67,3 \%)$ beresiko tinggi melakukan penyalahgunaan narkoba.

Sekolah yang kurang disiplin, terletak di dekat tempat hiburan, kurang memberi kesempatan pada siswa untuk mengembangkan diri secara kreatif dan positif, dan adanya murid pengguna NAPZA merupakan faktor kontributif terjadinya penyalahgunaan NAPZA (Simangunsong, 2009). Perilaku remaja tidak terlepas dari kontrol sosial yang ada. Oleh karena itu, sangat penting menegakkan disiplin yang dimulai di sekolah. Aturan yang tidak tegas tentang penyalahgunaan NAPZA dapat mempengaruhi perilaku remaja di sekolah. Siswa umumnya berada di sekolah 5-6 jam perhari.

Pada penelitian ini didapatkan nilai $\rho$ value $=0,02$ yang artinya ada hubungan yang signifikan antara sekolah dengan resiko penyalahgunaan narkoba pada siswa SMP di Kota Bengkulu. Sekolah dapat mempengaruhi kehidupan siswa sehari-hari, dimana tempat berkumpul dengan teman sebaya, selain itu menjadi ajang pertukaran pikiran. Sekolah dapat menjadi salah satu tempat yang efektif untuk perkenalan, pembagian, dan perdagangan NAPZA.

Pada penelitian ini didapatkan nilai $\mathrm{OR}=2.433$ artinya remaja dari sekolah yang mendukung terjadinya resiko penyalahgunaan 2,433 kali lebih beresiko melakukan penyalahgunaan narkoba dibandingkan dengan remaja dari sekolah yang tidak mendukung terjadinya resiko penyalahgunaan narkoba.

\section{e. Hubungan masyarakat dengan resiko penyalahgunaan narkoba}

Pada penelitian ini didapatkan lebih dari sebagian responden yang tinggal di lingkungan masyarakat yang mendukung terjadinya resiko penyalahgunaan narkoba $(67,7 \%)$ beresiko tinggi melakukan penyalahgunaan narkoba.

Lembaga kontrol sosial yang tidak berfungsi secara maksimal akan mengakibatkan terputusnya ikatan sosial masyarakat yang menyebabkan anggota masyarakat melakukan perilaku menyimpang (Suyatno, 2006 dalam Tambunan, Sahar, dan Hastono, 2008). Remaja menjadi pengguna NAPZA dimulai dengan penggunaan NAPZA yang seolah legal di masyarakat yaitu merokok. Penggunaan kemudian bertahap mencoba minum alkohol, mariyuana, dan ke tingkat yang lebih berat seperti ecstasy, heroin, dan shabu-shabu (Catio, 2006 dalam Tambunan, Sahar, dan Hastono, 2008).

Pada penelitian ini didapatkan nilai $\rho$ value $=0,003$ yang artinya ada hubungan yang signifikan antara masyarakat dengan resiko penyalahgunaan narkoba pada siswa SMP di Kota Bengkulu.

\section{KESIMPULAN}

1. Sebagian lebih dari sebagian responden $(57 \%)$ beresiko tinggi melakukan penyalahgunaan narkoba.

2. Ada hubungan antara jenis kelamin, keluarga, sekolah, dan masyarakat terhadap resiko penyalahgunaan narkoba pada siswa SMP di Kota Bengkulu. 


\section{SARAN}

1. Tenaga Kesehatan

Meningkatkan promosi pencegahan penyalahgunaan narkoba pada kalangan siswa SMP di Kota Bengkulu.

2. Keluarga

Orangtua harus menjalin komunikasi yang baik dengan anak sehingga anak dapat mengungkapkan permasalahannya pada orang tua dan tidak menggunakan narkoba, dan agar menjadi role model yang baik bagi anak.

\section{Sekolah}

Pihak sekolah harus meningkatkan kedisiplinan dan sanksi tegas bagi siswa yang menggunakan narkoba, dan melakukan edukasi tentang bahaya narkoba melalui kerjasama dengan pihak lain.

4. Masyarakat

Masyarakat harus segera melaporkan apabila ada pengguna atau pengedar narkoba ada di wilayah tempat tinggalnya.

\section{DAFTAR PUSTAKA}

Hawari, D. 1990. Pendekatan Psikiatri Klinis Pada Penyalahgunaan Zat. (Doctoral dissertation, Tesis)

Hawari, D. 1991. Penyalahgunaan narkoba dan zat adiktif. Jakarta: Fakultas Kedokteran Universitas Indonesia

Hurriyati, EA. 2010. Mengapa pengguna narkoba pada remaja akhir relapse? Humaniora Vol. 1 No.2 Oktober: 303314

Kaplan \& Sadock. 2005. Comprehensive textbook of Psychiatry. Pensylvania: Lippincot Williams \& Wilkins

Nur'artavia. 2017. Karakteristik pelajar penyalahguna NAPZA dan jenis
NAPZA yang digunakan di Kota Surabaya. The Indonesian Journal of Public Health Vol.12 No.1: 27-38.

Puslidatin BNN. 2017. Ringkasan eksekutif hasil survey BNN Tahun 2016

Setiawan, AA. 2017. Remaja Terhadap Penyalahgunaan NAPZA. Artikel Ilmiah. Www. Researchgate.net/publication/31578420 7

Setiawan, H.S. 2008. Faktor-faktor penyalahgunaan narkoba pada siswa sekolah lanjutan tingkat atas. Tesis. Universitas Indonesia

Supratman, D. 2018. Prevalensi Penyalahgunaan Narkoba di Indonesia dan Ancaman Bencana Demografi. www.diklat.bnn.go.id

Tambunan, Sahar, dan Hastono. 2008. Beberapa faktor yang berhubungan dengan perilaku penggunaan NAPZA pada remaja di Balai Pemulihan Sosial Bandung. Jurnal Keperawatan Indonesia. Volume 2, Juli 2008: 63-69.

Tasiam, Umboh, Rombot, dan Pelelau. 2013. Hubungan antara lingkungan sekolah, lingkungan keluarga, dan teman sebaya dengan perilaku yang menunjukkan resiko penyalahgunaan NAPZA pada Siswa SMK Negeri 3 Manado. Jurnal Ilmu Kesehatan Masyarakat Unsrat Vol. 3, No. 2

World Drug Report. 2018. United Nations Publications, Sales No E 18. XI. 9

4http://dedihumas.bnn.go.id/read/section/artik el/2013/07/23/704/faktor-penyebabpenyalahgunaannarkotika 